\title{
Role of $\beta$-adrenergic receptors in insulin resistance: Induction or protection?
}

Wael S. Ibrahim ${ }^{1,2}$, Islam A. A. E.-H. Ibrahim ${ }^{1}$, Amr A. A. Mahmoud ${ }^{1,3}$, Mona F. Mahmoud ${ }^{1}$

${ }^{1}$ Department of Pharmacology and Toxicology, Faculty of Pharmacy, Zagazig University, Egypt.

${ }^{2}$ Department of Pharmacology, School of Pharmacy, Badr University, Cairo, Egypt.

${ }^{3}$ Present address: Department of Pharmacology, Pharmacy Program, Oman College of Health Sciences, Muscat 114, Oman

*Corresponding author:

Islam A. A. E.-H. Ibrahim, Department of Pharmacology and Toxicology, Faculty of

Pharmacy, Zagazig University, 44519 Egypt.

E-mail: eaebrahiem@pharmacy.zu.edu.eg

Tel/Fax: +200552303266

Brief running title: $\beta$-adrenergic receptors and insulin resistance

Received: 18 May 2021 /Accepted: 8 Jun 2021 /Published online: 1 Oct 2021.

Abstract

$\beta$-Adrenergic receptors ( $\beta$ ARs), in particular $\beta 2$-subtype, are key regulators of glucose homeostasis. Previous studies showed that activation of hepatic and adipose tissue $\beta$ ARs mediates insulin desensitizing effects. On the contrary, activation of $\beta$ ARs in the skeletal muscle enhances glucose uptake. However, there is a lot of controversy regarding the metabolic effects of systemic administration of either $\beta$ AR agonists or antagonists. $\beta 2$-Agonists have been shown to substantially impair glucose homeostasis while improving it with long-term systemic administration. In the same context, acute and chronic systemic use of certain types of $\beta$ blockers have been found to enhance insulin action. In this review article, we try to elaborate the underlying mechanisms that regulate glucose metabolism after acute and chronic systemic use of $\beta A R$ agonists and antagonists in an attempt to answer the question "Do $\beta A R$ s induce or protect against insulin resistance?"

\section{Keywords}

$\beta$-Adrenergic receptors, insulin resistance, $\beta$-agonists, $\beta$-blockers, glucose homeostasis.

\section{Introduction}

$\beta$-Adrenergic receptors ( $\beta$ ARs) belong to $\mathrm{G}$ protein-coupled receptors (GPCRs) that bind to epinephrine and norepinephrine to mediate its physiological response (Hall, 2004). GPCRs are seven-transmembrane-spanning receptors that couple to the heterotrimeric Gprotein complex $(\mathrm{G} \alpha \beta \gamma)$ (Alexander et al., 2019). Activation of a GPCR induces a conformational change of the receptor and promotes guanosine diphosphate (GDP) exchange for guanosine triphosphate (GTP) via guanine nucleotide exchange factors causing dissociation of G-proteins into activated $\mathrm{G} \beta \gamma$ - and $\mathrm{G} \alpha$-proteins (Rockman et al., 2002). G $\alpha$-proteins are further classified into four major different types: $\mathrm{G} \alpha_{\mathrm{S}}, \mathrm{G} \alpha_{\mathrm{i}}, \mathrm{G} \alpha_{\mathrm{q}}$, and $\mathrm{G} \alpha_{12}$ (Madamanchi, 2007).

$\beta A R s$ are also subdivided into three subtypes: $\beta 1 \mathrm{AR}$ is mainly found in the heart and brain (Frielle et al., 1987), $\beta 2 \mathrm{AR}$ is more widely distributed (Dixon et al., 1986), and $\beta 3 \mathrm{AR}$ is mainly found in adipose tissue (Emorine et al., 1989). The three subtypes couple primarily to $\mathrm{G} \alpha_{\mathrm{s}}$ to stimulate adenylyl cyclase but can also couple to $\mathrm{G} \alpha_{\mathrm{i}}$ to inhibit adenylyl cyclase (AC) in some cells under certain conditions (Daaka et al., 1997; Soeder et al., 1999; Xiang et al., 2002). Coupled to 
Gas, the $\beta$ ARs activate AC, cyclic adenosine monophosphate (cAMP) synthesis, and protein kinase A (PKA) activity (Halls and Cooper, 2017).

In the heart, $\beta 1 \mathrm{AR}$ is 4-times more expressed than $\beta 2 A R$ (Cannavo et al., 2013). The expression of $\beta 3 \mathrm{AR}$ is very low in normal heart but it is upregulated during heart failure (Moniotte et al., 2001). On the contrary, $\beta 1 \mathrm{AR}$ decreases during heart failure, while the expression of $\beta 2 A R$ increases, reaching a ratio of 3:2 (Bristow et al., 1986). Upon prolonged cardiac $\beta 1 \mathrm{AR}$ stimulation, the levels of $\beta 1 \mathrm{AR}$ at the plasma membrane decrease and $G \alpha_{\text {s }}$ becomes uncoupled from AC. This diminishes cAMP production, yet induces the activation of calcium/calmodulin kinase (CaMK)II, which promotes hypertrophy in cardiomyocytes (Zhang et al., 2003; Tilley and Rockman, 2006).

Persistent cardiac $\beta 2 \mathrm{ARs}$ activation can cause coupling of the receptor to the ${\mathrm{G} \alpha \mathrm{i}^{-}}^{-}$ pathway under the influence of G-proteincoupled receptor kinase (GRK) 2 and/or GRK5 and PKA and/or protein kinase C (PKC) phosphorylation (Lefkowitz, 1998). This might opposes the positive inotropic effects mediated via Gos, which in turn, activates a cell survival pathway (Communal et al., 1999).

In contrast to their clear roles in cardiac muscle activity, $\beta$ ARs' role in insulin resistance and glucose homeostasis is highly controversial. In this review, we discuss the different metabolic effects of $\beta$ ARs and try to resolve the controversy regarding their roles.

\section{Insulin resistance}

Insulin resistance is a condition where body cells become resistant to insulin effects, resulting in abnormally large amount of insulin to attain a normal biologic response (Petersen and Shulman 2018). Indeed, the resistance occurs with both endogenous and exogenous insulin. Resistance to endogenous insulin in the muscle, fat, and liver cells is compensated by elevated serum insulin concentration accompanied with normal or increased glucose concentration (Yaribeygi et al., 2019). Insulin resistance is the crucial causative mechanism of type II diabetes and is highly correlated with increased risk of hypertension, and cardiovascular diseases (Wilcox, 2005).

Insulin resistance may be due to defects either before insulin binds to its receptor, at the level of the insulin receptor, or at a level beyond the downstream signaling.

Insulin receptor defect is generally caused by genetic mutations in the insulin receptor gene leading to defects in receptor number, structure, binding, affinity, or signaling capacity (Haeusler et al., 2018; Melvin et al., 2018).

Post-insulin receptor defect is caused by several pathways that either mediate degradation of the insulin receptor substrate1 (IRS-1) by serine phosphorylation, inhibition of insulin receptor-IRS-1 interaction, or inhibition of protein kinase B (Akt) serine 473 phosphorylation (Shimobayashi et al., 2018). Free fatty acids can elevate intracellular diacylglycerol (DAG) level that mediates the activation of PKC and degradation of IRS-1 (Wang et al., 2009; Nandipati et al., 2017; Palomer et al., 2018). In the same way, inflammatory cytokines promote PKC-activation/IRS-1 degradation and inhibit insulin receptor-IRS1 interaction (Wu and Ballantyne, 2017). On the other hand, $\beta$-arrestin2, a GPCR desensitizing and scaffolding protein, has been found to play a critical role in insulin signaling by mediating the interaction between IRS-1, Src and Akt to promote serine 473 phosphorylation of the latter (Luan et al., 2009). Notably, $\beta$-arrestin 2 is downregulated during type II diabetes, insulin resistance, and obesity (Feng et al., 
2011). Furthermore, feeding rodents high fat and high fructose diets has been found to downregulate $\beta$-arrestin2 in the classical insulin target tissues such as liver, skeletal muscle, and adipose tissue causing insulin resistance (Zhu et al., 2017; El-Fayoumi et al., 2020).

Noteworthy, the insulin resistance progression to cardiovascular disease or type II diabetes can be divided into four stages. Stage I of insulin resistance is distinguished by craving to carbohydrates, mild insulin resistance, and gaining weight easily as increased amount of food energy (transformed into blood sugar) is directed to the liver, converted into blood fat, and then stored in fat cells (Wurtman et al., 1981). Moreover, in stage I, a diet rich in carbohydrate (within $2 \mathrm{~h}$ ) may result in irritability, tiredness, or poor concentration. Though, these signs and symptoms may differ among individuals. However, fasting levels of insulin and blood glucose remain within the normal range (Reddy et al., 2010). Stage II of insulin resistance is characterized by normal or increased fasting insulin levels, normal blood glucose, mild-to-moderate central obesity, high blood pressure, early atherogenic dyslipidemia, vascular inflammation with elevated circulating levels of inflammatory markers, and endothelial dysfunction (DeFronzo, 1997; Patil and Watve, 2010).

This is followed by stage III of insulin resistance, which is characterized by high fasting insulin levels, impaired glucose tolerance (prediabetes), advanced atherogenic dyslipidemia including increased lipoproteins containing apolipoprotein B, triglycerides, elevated small dense lowdensity lipoprotein (LDL) particles, and decreased levels of high-density lipoproteins (HDLs) and prothrombotic stage signifying anomalies in procoagulant factors, antifibrinolytic factors and platelet aberrations. Noteworthy, stage III of insulin resistance is collectively termed metabolic syndrome (DeFronzo and Ferrannini, 1991; Fukushima et al., 2004).

In the $4^{\text {th }}$ stage of insulin resistance, there is a complete resistance of body cells to insulin and this stage is marked by high levels of fasting insulin and blood glucose levels. Notably, stage IV is the first onset of frank type II diabetes mellitus and advanced atherosclerotic changes with strong potential for cardiovascular disease and its complications (Reddy et al., 2010).

\section{1 $\beta$-Adrenergic receptors and hepatic insulin resistance}

Catecholamines, such as epinephrine and norepinephrine, can regulate liver metabolism by activating hepatic $\beta$ ARs and its coupled $\mathrm{G} \alpha_{\mathrm{s}}$ protein (Dax et al., 1987; Katz et al., 1987; Arner et al., 1990). Both $\beta 1-$ and $\beta 2$-ARs are expressed in the liver, and their expression increases with aging (Arner et al., 1990). However, the hepatic level of $\beta 2 A R$ is higher than $\beta 1$-subtype. Activation of the $\beta A R s / G \alpha_{s} / A C$ pathway increases hepatic glucose output and liver lipid catabolism (Aggerbeck et al., 1983; Erraji-Benchekroun et al., 2005; Ghosh et al., 2012). In rat hepatocytes, the activation of $\beta A R s$ with the nonselective agonist isoproterenol increases glycogen phosphorylase activity by many folds and decreases liver glycogen levels (ErrajiBenchekroun et al., 2005). Moreover, the activation of hepatic $\beta$ ARs by isoproterenol or in vitro overexpression of them is associated with increase in liver lipid accumulation and development of hepatic steatosis that may lead to hepatic insulin resistance (Ghosh et al., 2012; Hurr et al., 2019). 


\section{$2.2 \beta$-Adrenergic receptors and skeletal muscle insulin resistance}

The three $\beta A R$-subtypes are expressed in skeletal muscle with highest abundance for $\beta 2 \mathrm{AR}$ (Williams et al., 1984;

Kim et al., 1991). Slow-twitch muscles, such as the soleus muscle, have a greater density of $\beta$ ARs than fast-twitch muscles, such as the extensor digitorum longus (EDL) (Martin 3rd et al., 1989; Ryall et al., 2002; Ryall et al., 2004). Notably, the response to $\beta$-agonist administration appears to be greater in fastthan in slow-twitch skeletal muscles (Ryall et al., 2002; Ryall et al., 2006). In skeletal muscle, all $\beta$ ARs can couple to either $\mathrm{G}_{\mathrm{s}^{-}}$or $\mathrm{G} \alpha_{\mathrm{i}}$-proteins with more predominance for the $\mathrm{G} \alpha_{s}$-subtype (Xiao et al., 1999; Gosmanov et al., 2002). Furthermore, both ${\mathrm{G} \alpha \mathrm{i}^{-}}$and $\mathrm{G}_{\beta \gamma^{-}}$ proteins can initiate intracellular signaling pathways independent of $\mathrm{G} \alpha_{\mathrm{s}}$-proteins (Glukhova et al., 2018).

Noteworthy, $\mathrm{G}_{\beta \gamma}$-proteins activation by $\beta$-agonists mediates activation of the phosphatidyl inositol 3-kinase (PI3K)/Akt pathway (Murga et al., 1998; Campbell and Smrcka, 2018). As we mentioned previously, Akt activation stimulates both glucose uptake and glycogen synthesis (Beg et al., 2017). Therefore, theoretically activation of the $\beta A R / \mathrm{G}_{\beta \gamma} / \mathrm{PI} 3 \mathrm{~K} / \mathrm{Akt}$ pathway by $\beta$-agonists should enhance insulin signaling in skeletal muscle.

On the other hand, activation of the AC/cAMP/PKA pathway in skeletal muscle has been found to promote muscle hypertrophy, increase muscle mass, and increase glucose uptake capacity, which may ameliorate systemic insulin resistance (Chen et al., 2005; Al-Ozairi et al., 2021). However, there is a lot of controversy about this role in skeletal muscle. A previous study showed that $\beta$ ARs activation mediates low level of apoptosis in skeletal muscle and this effect is mediated by the $\beta 2$-subtype not $\beta 1$ like in cardiac muscles (Burniston et al., 2005; Burniston et al., 2006).

$2.3 \beta$-Adrenergic receptors and adipose tissue insulin resistance

Like liver and skeletal muscles, adipose tissue expresses the three subtypes of $\beta A R s$ (Collins and Surwit 2001). All subtypes promote triglycerides hydrolysis and release of free fatty acids (FFAs) in blood stream (Arner, 1992). The underlying mechanisms differ among the $\beta A R$-subtypes. $\beta 2 A R$ mediates the activation of the $G \alpha_{s^{-}}$ protein/AC/cAMP/PKA pathway, which then mediates the activation of hormone sensitive lipases (Collins et al., 2004). In addition, PKA phosphorylates $\beta 2 \mathrm{AR}$ impeding further interaction with $\mathrm{G} \alpha_{\mathrm{s}}$-protein while promoting its interaction with ${\mathrm{G} \alpha \mathrm{i}^{-}}^{-}$ protein (Zamah et al., 2002). Then, $\mathrm{G} \alpha_{\mathrm{i}}-$ protein mediates the activation of the extracellular regulated kinase (ERK), which causes lipid hydrolysis (Greenberg et al., 2001; Collins et al., 2004). On the other hand, $\beta 3 \mathrm{AR}$ can mediate lipid hydrolysis by concurrent activation of both ${\mathrm{G} \alpha \mathrm{s}^{-}}$and $\mathrm{G \alpha}_{\mathrm{i}^{-}}$ proteins while $\beta 1 \mathrm{AR}$ can behave similar to both $\beta 2$ - and $\beta 3$-AR (Soeder et al., 1999; Collins, 2012).

As mentioned earlier, increased circulating levels of FFAs is highly correlated with systemic insulin resistance through activation of FFA receptors (FFARs) in different types of body tissues, particularly the skeletal muscle. Therefore theoretically, $\beta$-agonists can mediate systemic insulin resistance by increasing FFAs circulating levels.

If we consider the findings of previous reports, it seems that $\beta$-agonists can mediate systemic insulin resistance by acting on $\beta$ ARs in liver and adipose tissue (Fig. 1). On the contrary, $\beta$-agonists enhance insulin signaling and promote glucose uptake by acting on $\beta A R s$ in skeletal muscle. The 
question that arises is "Which effect predominates after systemic administration?" To get a plausible answer, we discuss the in vivo and in vitro actions of $\beta$-agonists and antagonists and their effects on systemic insulin resistance.

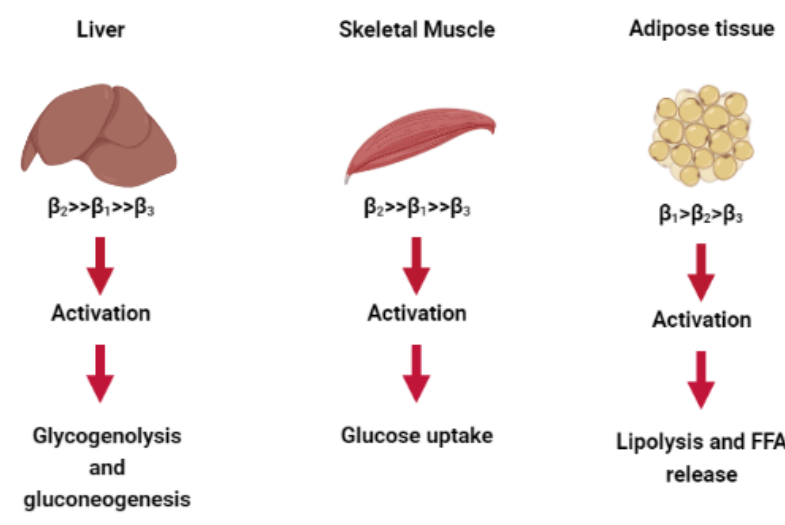

Figure 1: Expression of $\beta$-adrenergic receptors in liver, skeletal muscles and adipose tissue and their effects on glucose homeostasis.

3. Ligands of $\beta$-adrenergic receptors and their effects on systemic insulin resistance

\subsection{Epinephrine}

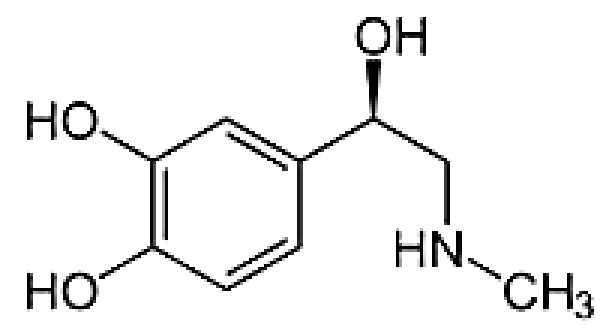

\section{4-[(1R)-1-hydroxy-2-(methylamino) ethyl] benzene-1,2-diol}

It is a sympathomimetic catecholamine that can stimulate both $\alpha$ - and $\beta$-ARs (Wong et al., 2012). There is a lot of controversy about the metabolic effects of epinephrine, which seems to be highly dependent on the dose and duration of administration in addition to circulating insulin level. Epinephrine, in low dose, has been found to induce hyperglycemia by inhibiting glucose uptake in peripheral tissues and increasing hepatic glucose output. However, in high dose, it induces hyperglycemia by promoting glucagon secretion that inhibits insulin release, reduces glucose uptake, and increases hepatic glucose output (Gray et al., 1980; Sherwin and Sacca, 1984; Nachar et al., 2011). In the same context, epinephrine increases blood glucose levels acutely. However, the chronic effect of epinephrine on blood glucose levels are not clear. A previous study showed that 70-h infusion of epinephrine in combination with other stress hormones elevates blood glucose levels and this effect is highly dependent on epinephrine (McGuinness et al., 1997). On the contrary, another study reported low urine epinephrine levels in patients with metabolic syndrome and that decreased adrenal medullary epinephrine secretion may contribute to the dyslipidemia developed in the insulin resistance syndrome (Ward et al., 1994).

Moreover, it has been found that epinephrine possesses both a stimulatory and inhibitory effect on peripheral glucose uptake. The stimulatory effect was seen on basal glucose uptake and was much smaller than the effect of insulin, however, epinephrine inhibited insulin-mediated glucose uptake by rat hindlimbs and this effect was mediated by $\beta$ ARs as it was totally inhibited by $\beta$-blockers such as propranolol, but unaffected by $\alpha$ blockers such as phentolamine (Chiasson et al., 1981). In the same context, another study demonstrated that epinephrine is capable of inhibiting glucose transport activated by a moderate, but not a high, physiological insulin concentration. In this study epinephrine (24 nM) inhibited glucose transport in the presence of $50 \mu \mathrm{U} / \mathrm{ml}$ insulin in both the epitrochlearis and soleus muscles. However, when muscles were incubated in $100 \mu \mathrm{U} / \mathrm{ml}$ insulin, neither 24 nor $500 \mathrm{nM}$ of epinephrine had significant effects on glucose transport (Hunt and Ivy, 2002). 


\subsection{Norepinephrine}

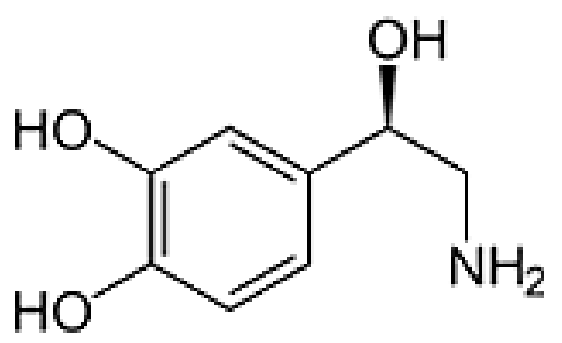

\section{4-[(1R)-2-amino-1-hydroxyethyl] benzene-1,2-diol}

It is a sympathomimetic catecholamine that can stimulate $\alpha$ ARs more than $\beta$ ARs. In addition, norepinephrine induces less $\beta 2 \mathrm{AR}$ coupling with $G \alpha_{i}$ protein than epinephrine (Wang et al., 2008). In contrast to epinephrine, all studies performed on norepinephrine showed acute and chronic systemic insulin desensitizing effects, which may be attributed to the higher activity of norepinephrine on $\alpha A R s$ than $\beta A R s$ and the low coupling with $\mathrm{G} \alpha_{i}$ protein (Marangou et al., 1988; Penesova et al., 2008; Khoury and McGill, 2011).

\subsection{Isoproterenol}

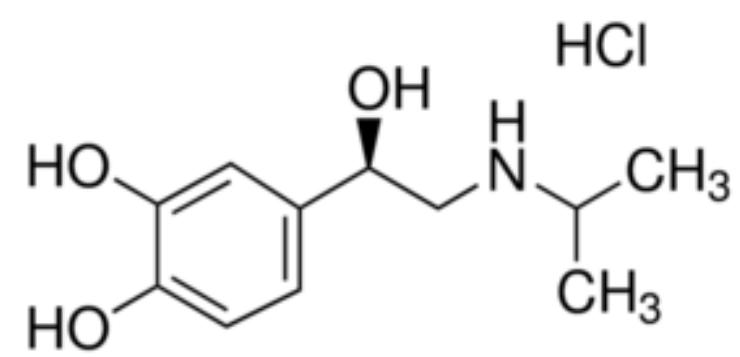

4-[1-Hydroxy-2-(isopropylamino) ethyl]1,2-benzenediol

Isoproterenol is a synthetic non selective $\beta A R$ full agonist used as a potent cardiac stimulant (Zuppa and Barrett 2008). Like epinephrine, systemic administration of isoproterenol acutely increases hepatic glucose output and induces insulin resistance (Hoff and Koh, 2018). Unlike epinephrine, the chronic systemic effect of isoproterenol on glucose homeostasis shows a clear increase in systemic insulin sensitivity
(Rousseau-Migneron et al., 1980; Heather et al., 2009; Sato et al., 2014). Taking in consideration that isoproterenol activates $\beta$ ARs without affecting $\alpha$ ARs and epinephrine activates both types, this may be the first evidence that chronic systemic activation of $\beta$ ARs protects against insulin resistance.

\subsection{Clenbuterol}<smiles>CC(C)(C)NCC(O)c1cc(Cl)c(N)c(Cl)c1</smiles>

\section{1-(4-Amino-3,5-dichlorophenyl)-2-[(2-} methyl-2-propanyl) amino] ethanol

Clenbuterol is a 32 -agonist approved in the United States for veterinary use in non-food animals (Spiller et al., 2013). It stimulates $\beta 2 A R$ coupling with $G \alpha_{i}$ protein like epinephrine and more than norepinephrine (Evans et al., 2013). Clenbuterol acutely decreases glucose uptake in skeletal muscle (Evans et al., 2013; Nagla et al., 2013), while chronic systemic administration clearly induces insulin sensitizing effects associated with increased muscle mass, enhanced skeletal muscle glucose uptake, and reduced visceral adiposity (Pan et al., 2001). Interestingly, other selective $\beta 2$-agonists such as salbutamol, salmeterol, formoterol, and terbutaline showed identical metabolic effects to those of clenbuterol during both acute and chronic administration (Philipson, 2002). This is an additional strong evidence supporting the hypothesis that chronic systemic activation of $\beta$ ARs, especially $\beta 2 \mathrm{AR}$, protects against insulin resistance.

\subsection{Propranolol}




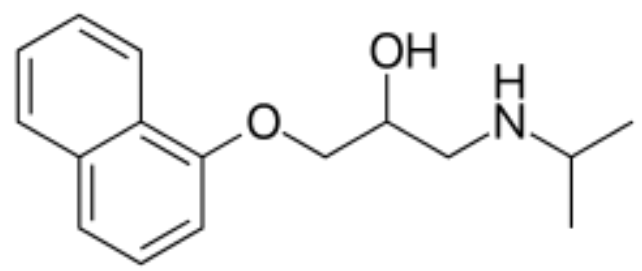

2-Propanol,

1-(isopropylamino)-3-(1naphthyloxy)

Propranolol is a nonselective $\beta$-blocker that inhibits the sympathetic effects of catecholamines through $\beta$ ARs (Routledge and shand, 1979). Later, it has been found that propranolol is an inverse agonist to $\beta A R s$ (i.e., it decreases the constitutive activity of these receptors). Moreover, propranolol binds to $\beta A R s$ to activate $\beta$-arrestin/ERK pathway (Luttrell, 2005). There is a lot of controversy regarding both the acute and chronic systemic metabolic effects of propranolol. Some studies such as that conducted by Allison et al., 1969 showed acute systemic insulin sensitizing effects for propranolol probably by inhibiting mobilization of muscle glycogen, lactateinduced hepatic gluconeogenesis, and FFAs release from triglycerides (Allison et al., 1969). Other studies such as that conducted by Cerasi et al., 1972 showed acute systemic hyperglycemic effects for propranolol mediated by the inhibition of insulin secretion in response to glucose infusion. On the other hand, Akçay et al., 2005 and da Silva Franco et al., 2017 showed chronic systemic insulin sensitizing and hypoglycemic effects of propranolol in thermally injured patients and obese mice fed high-fat diet, respectively. The latter effect was probably mediated by blocking $\beta 2 \mathrm{AR}$ (da Silva Franco et al., 2017). On the contrary, Groop et al., 1983 showed chronic systemic hyperglycemic effects of propranolol in hypertensive non-diabetic patients after an intravenous glucose tolerance test without affecting insulin secretion.

\subsection{Carvedilol}

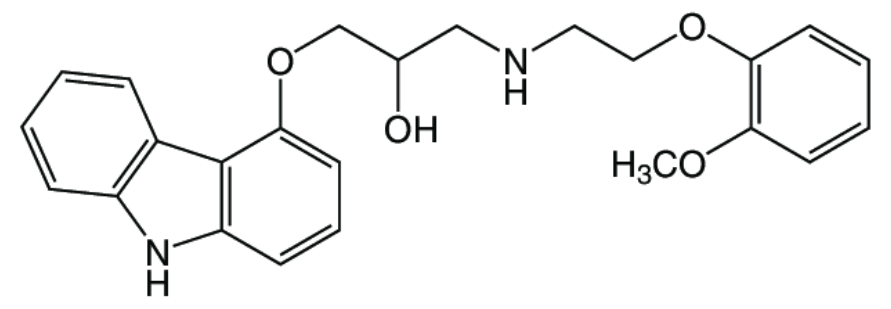

1-(9H-carbazol-4-yloxy)-3-\{[2-(2methoxyphenoxy) ethyl] amino\} propan-2ol

Carvedilol is a third generation non cardioselective $\beta$-blocker with weak $\alpha 1$ blocking actions (Mohamed et al., 2019; Ibrahim et al., 2020; Rezk et al., 2021). In addition, carvedilol has also been reported to have antioxidant properties (Abreu et al., 2000; Rolo et al., 2003; Akbas et al., 2005). Later, it has been classified as the first member in the $\beta$-arrestin biased agonists (Wisler et al., 2007). Unlike previous drugs, there are no studies that addressed the acute systemic effects of carvedilol on glucose homeostasis. Therefore, our work group investigated these systemic acute effects in both normal and insulin resistant mice (data under publication). We found that carvedilol did not significantly change glucose tolerance in both normal and insulin-resistant mice after $30 \mathrm{~min}$ of intraperitoneal injection. However, carvedilol increased insulin sensitivity in normal mice after $30 \mathrm{~min}$ of intraperitoneal injection as assessed by intraperitoneal insulin tolerance test (ITT). Regarding the chronic systemic effects of carvedilol on glucose homeostasis, most studies support the insulin sensitizing effects of carvedilol probably by blocking $\alpha 1 \mathrm{AR}$ and subsequent dilation of blood vessels (Jacob, 1999; Basat et al., 2006; Ozyıldız et al., 2017). Interestingly, our work and another recent research article showed potential role for $\beta$ - 
arrestin2 protein in mediating the insulin sensitizing effects of carvedilol (Güven et al., 2020; Ibrahim et al., 2020).

\subsection{Atenolol}<smiles>CC(C)NCC(O)COc1ccc(CC(N)=O)cc1</smiles>

2-\{4-[2-Hydroxy-3-(propan-2-ylamino) propoxy] phenyl $\}$ acetamide

Atenolol is a selective $\beta 1 \mathrm{AR}$ blocker approved by US Food and Drug Administration (FDA) for the treatment of hypertension, angina pectoris, and acute myocardial infarction (Wadworth et al., 1991). Unlike propranolol and carvedilol, acute systemic administration of atenolol does not prolong hypoglycemia after insulin injection and does not affect glucose homeostasis confirming the potential role of $\beta 2 \mathrm{AR}$ in mediating these effects of propranolol and carvedilol (Deacon, 1977; Lyngsøe et al., 1983; Liu et al., 1996). On the contrary, chronic systemic administration of atenolol clearly induces insulin resistance that is highly correlated with systemic dyslipidemia (Pollare et al., 1989; Kuperstein and Sasson, 2000; Reneland et al., 2000; Poirier et al., 2001; Bharati and Singh 2016; Sirenko et al., 2017).

Regarding previous discussion, there is a strong evidence that systemic activation of $\beta 2$ ARs causes hyperglycemia and insulin resistance within few minutes to hours while improves glucose homeostasis and insulin sensitivity within few days to weeks. This means that the acute systemic effects of $\beta 2$ agonists on glucose homeostasis are highly correlated with their effects on hepatic and adipose tissue $\beta 2$ ARs not skeletal muscle receptors. In other words, the contribution of skeletal muscle to systemic glucose homeostasis after systemic administration of $\beta 2$-agonists is relatively weak compared to liver and adipose tissue. On the other hand, systemic blocking of $\beta 2 \mathrm{ARs}$ acutely prolongs hypoglycemia after insulin administration while improves glucose homeostasis and insulin sensitivity within few days to weeks. The acute systemic effects of either activation or blocking of $\beta 2 \mathrm{ARs}$ on glucose homeostasis are reasonable and comprehensible. On the contrary, the chronic effects are obscure and require more clearer interpretation. Therefore, we discuss next the role of $\mathrm{G} \alpha_{\mathrm{i}}$-protein/ $\beta$-arrestin pathway in mediating these effects. We summarized the distinct effects of $\beta$ ARs-ligands on systemic insulin resistance in Table 1.

4. $G \alpha_{i} / \beta$-arrestin pathway and the metabolic effects of $\beta 2$-adrenergic receptors

$\mathrm{G} \alpha \alpha_{\mathrm{i}}$-protein is a subtype of the $\mathrm{G} \alpha$ proteins family that includes $\mathrm{G} \alpha_{\mathrm{i} / \mathrm{o}}, \mathrm{G} \alpha_{\mathrm{s}}$, $\mathrm{G} \alpha_{\mathrm{q} / 11}$, and $\mathrm{G} \alpha_{12 / 13}$. $\mathrm{G} \alpha_{\mathrm{i}}$-protein inhibits the activity of AC leading to decreased cAMP formation (De Oliveira et al., 2019). Recently, a close interplay between ${\mathrm{G} \alpha \mathrm{i}^{-}}^{-}$ protein and $\beta$-arrestins has been disclosed (Dwivedi et al., 2018). $\beta$-arrestins are GPCRs desensitizing proteins, which have been found later to activate $G$ proteinindependent signaling (Jean-Charles et al., 2017). 
Table 1: Ligands of $\beta$-adrenergic receptors and their effects on systemic insulin resistance

\begin{tabular}{|c|c|c|c|c|c|}
\hline Drug & $\begin{array}{l}\text { Subject/ } \\
\text { Species }\end{array}$ & Dose/Route/model & $\begin{array}{l}\text { Receptor/ } \\
\text { mediator }\end{array}$ & Effect & Reference \\
\hline \multirow[t]{6}{*}{ Epinephrine } & Humans & $1.2 \mu \mathrm{g} / \mathrm{m}^{2} / \mathrm{min}$; infusion; acute & $\alpha / \beta$-ARs & $\begin{array}{l}\text { Insulin } \\
\text { resistance }\end{array}$ & Sherwin and Sacca, 1984 \\
\hline & Dogs & $\begin{array}{l}0.1-0.2 \mu \mathrm{g} / \mathrm{kf} / \mathrm{min} ; \text { infusion; } \\
\text { acute }\end{array}$ & $\alpha / \beta$-ARs & $\begin{array}{l}\text { Insulin } \\
\text { resistance }\end{array}$ & Gray et al., 1980 \\
\hline & Piglets & $\begin{array}{l}0.25-2 \mu \mathrm{g} / \mathrm{kg} / \mathrm{min} ; \text { infusion; } \\
\text { acute }\end{array}$ & $\alpha / \beta$-ARs & $\begin{array}{l}\text { Insulin } \\
\text { resistance }\end{array}$ & Nachar et al., 2011 \\
\hline & $\begin{array}{l}\text { Skeletal } \\
\text { muscle }\end{array}$ & $10 \mathrm{nM}-0.1 \mu \mathrm{M} ;$ acute & $\beta \mathrm{AR}$ & $\begin{array}{l}\text { Insulin } \\
\text { resistance }\end{array}$ & Chiasson et al., 1981 \\
\hline & $\begin{array}{l}\text { Skeletal } \\
\text { muscle }\end{array}$ & $24 \mathrm{nM}$; acute & $\beta \mathrm{AR}$ & $\begin{array}{c}\text { Insulin } \\
\text { sensitization }\end{array}$ & Hunt and Ivy 2002 \\
\hline & Dogs & $\begin{array}{l}0.08 \mu \mathrm{g} / \mathrm{kg} / \mathrm{min} ; \text { infusion; } \\
\text { chronic }\end{array}$ & $\alpha / \beta$-ARs & $\begin{array}{l}\text { Insulin } \\
\text { resistance }\end{array}$ & McGuinness et al., 1997 \\
\hline \multirow[t]{3}{*}{ Norepinephrine } & Humans & $25 \mathrm{ng} / \mathrm{kg} / \mathrm{min}$; infusion; acute & $\alpha / \beta$-ARs & $\begin{array}{c}\text { Insulin } \\
\text { resistance }\end{array}$ & Marangou et al., 1988 \\
\hline & Humans & 110 ng/kg/min; infusion; acute & $\alpha / \beta$-ARs & $\begin{array}{c}\text { Insulin } \\
\text { resistance }\end{array}$ & Khoury and McGill, 2011 \\
\hline & $\begin{array}{c}\text { 3T3-L1 } \\
\text { Adipocytes }\end{array}$ & $1 \mu \mathrm{M}$; acute & $\beta A R$ & $\begin{array}{c}\text { Insulin } \\
\text { resistance }\end{array}$ & Mulder et al., 2005 \\
\hline \multirow[t]{5}{*}{ Isoproterenol } & Humans & Drip; acute & $\beta \mathrm{AR}$ & $\begin{array}{l}\text { Insulin } \\
\text { resistance }\end{array}$ & Hoff and Koh 2018 \\
\hline & $\begin{array}{l}\text { Skeletal } \\
\text { muscle }\end{array}$ & $1 \mathrm{mg} / \mathrm{kg}$; intraperitoneally; acute & $\beta A R$ & $\begin{array}{c}\text { Insulin } \\
\text { sensitization }\end{array}$ & Sato et al., 2014 \\
\hline & Rats & $\begin{array}{c}300 \mu \mathrm{g} / \mathrm{kg} / \mathrm{day} ; \text { subcutaneous; } \\
\text { chronic }\end{array}$ & $\beta A R$ & $\begin{array}{c}\text { Insulin } \\
\text { sensitization }\end{array}$ & $\begin{array}{c}\text { Rousseau-Migneron et al., } \\
1980 \\
\end{array}$ \\
\hline & Rats & $5 \mathrm{mg} / \mathrm{kg} /$ day; infusion; chronic & $\beta A R$ & $\begin{array}{c}\text { Insulin } \\
\text { sensitization }\end{array}$ & Heather et al., 2009 \\
\hline & $\begin{array}{l}\text { Swiss albino } \\
\text { mice }\end{array}$ & $\begin{array}{c}5 \mathrm{mg} / \mathrm{kg} / \text { day; Intraperitoneally; } \\
\text { chronic }\end{array}$ & $\beta A R$ & $\begin{array}{c}\text { Insulin } \\
\text { sensitization }\end{array}$ & Under publication \\
\hline \multirow[t]{4}{*}{ Clenbuterol } & $\begin{array}{c}\text { Skeletal } \\
\text { muscle }\end{array}$ & $100 \mathrm{nM} ;$ acute & $\beta 2 \mathrm{AR}$ & $\begin{array}{l}\text { Insulin } \\
\text { resistance }\end{array}$ & Nagla et al., 2013 \\
\hline & $\begin{array}{c}\text { Skeletal } \\
\text { muscle }\end{array}$ & $0.5 \mathrm{mg} / \mathrm{kg} /$ day; orally; chronic & $\beta 2 \mathrm{AR}$ & $\begin{array}{c}\text { Insulin } \\
\text { sensitization }\end{array}$ & Hunt et al., 2002 \\
\hline & fa/fa Rats & $1 \mathrm{mg} / \mathrm{kg} /$ day; orally; chronic & $\beta 2 \mathrm{AR}$ & $\begin{array}{c}\text { Insulin } \\
\text { sensitization }\end{array}$ & Pan et al., 2001 \\
\hline & $\begin{array}{l}\mathrm{C} 57 \mathrm{Bl} / 6 \mathrm{~N} \\
\text { mice }\end{array}$ & $\begin{array}{c}0.025 \mathrm{mg} / \mathrm{kg} / \mathrm{day} ; \\
\text { Intraperitoneally; chronic }\end{array}$ & $\beta 2 \mathrm{AR}$ & $\begin{array}{c}\text { Insulin } \\
\text { sensitization }\end{array}$ & Kalinovich et al., 2020 \\
\hline \multirow[t]{5}{*}{ Propranolol } & Humans & 200 mg/day; orally; acute & $\beta A R$ & $\begin{array}{c}\text { Insulin } \\
\text { sensitization }\end{array}$ & Allison et al., 1969 \\
\hline & Humans & $2 \mathrm{mg} / \mathrm{kg} /$ day; orally; chronic & $\beta A R$ & $\begin{array}{c}\text { Insulin } \\
\text { sensitization }\end{array}$ & Akçay et al., 2005 \\
\hline & Humans & 160 mg/day; orally; chronic & $\beta A R$ & $\begin{array}{c}\text { Insulin } \\
\text { resistance }\end{array}$ & Groop et al., 1983 \\
\hline & $\begin{array}{c}\text { C57BL/6J } \\
\text { mice }\end{array}$ & $10 \mathrm{mg} / \mathrm{kg} /$ day; chronic & $\beta 2 \mathrm{AR}$ & $\begin{array}{l}\text { Insulin } \\
\text { sensitization }\end{array}$ & $\begin{array}{l}\text { da Silva Franco et al., } \\
2017 \\
\end{array}$ \\
\hline & $\begin{array}{c}\text { Swiss albino } \\
\text { mice }\end{array}$ & $\begin{array}{c}30 \mathrm{mg} / \mathrm{kg} / \mathrm{day} ; \\
\text { Intraperitoneally; chronic }\end{array}$ & $\beta A R$ & $\begin{array}{c}\text { Insulin } \\
\text { sensitization }\end{array}$ & Under publication \\
\hline \multirow[t]{4}{*}{ Carvedilol } & Humans & $50 \mathrm{mg} /$ day; orally; chronic & $\beta \mathrm{AR} / \alpha 1 \mathrm{R}$ & $\begin{array}{c}\text { Insulin } \\
\text { sensitization }\end{array}$ & Basat et al., 2006 \\
\hline & Humans & $25 \mathrm{mg} /$ day; orally; chronic & $\beta \mathrm{AR} / \alpha 1 \mathrm{R}$ & $\begin{array}{c}\text { Insulin } \\
\text { sensitization }\end{array}$ & Ozyıldız et al., 2017 \\
\hline & Rats & $10 \mathrm{mg} / \mathrm{kg} /$ day; orally; chronic & $\beta$-Arrestins & $\begin{array}{c}\text { Insulin } \\
\text { sensitization }\end{array}$ & Güven et al., 2020 \\
\hline & $\begin{array}{l}\text { Swiss albino } \\
\text { mice }\end{array}$ & $\begin{array}{c}10 \mathrm{mg} / \mathrm{kg} / \mathrm{day} ; \\
\text { Intraperitoneally; chronic }\end{array}$ & $\begin{array}{c}\alpha 1 \mathrm{R} / \beta \mathrm{AR} / \beta- \\
\text { Arrestin2 }\end{array}$ & $\begin{array}{c}\text { Insulin } \\
\text { sensitization }\end{array}$ & Ibrahim et al., 2020 \\
\hline \multirow[t]{9}{*}{ Atenolol } & Humans & $5 \mathrm{mg}$; intravenous; acute & $\beta 1 \mathrm{AR}$ & Neutral & Lyngsøe et al., 1983 \\
\hline & Humans & 100 mg/day; orally; acute & $\beta 1 \mathrm{AR}$ & Neutral & Deacon 1977 \\
\hline & $\begin{array}{l}\text { Skeletal } \\
\text { muscle }\end{array}$ & $10 \mathrm{nM}-1 \mu \mathrm{M} ;$ acute & $\beta 1 \mathrm{AR}$ & Neutral & Liu et al., 1996 \\
\hline & Humans & $50 \mathrm{mg} /$ day; orally; chronic & $\beta 1 \mathrm{AR}$ & $\begin{array}{c}\text { Insulin } \\
\text { resistance }\end{array}$ & Pollare et al., 1989 \\
\hline & Humans & $50-100 \mathrm{mg} /$ day; orally; chronic & $\beta 1 \mathrm{AR}$ & $\begin{array}{l}\text { Insulin } \\
\text { resistance }\end{array}$ & $\begin{array}{l}\text { Kuperstein and Sasson, } \\
2000 \\
\end{array}$ \\
\hline & Humans & 50-100 mg/day; orally; chronic & $\beta 1 \mathrm{AR}$ & $\begin{array}{c}\text { Insulin } \\
\text { resistance }\end{array}$ & Reneland et al., 2000 \\
\hline & Humans & $50-100 \mathrm{mg} /$ day; orally; chronic & $\beta 1 \mathrm{AR}$ & $\begin{array}{c}\text { Insulin } \\
\text { resistance }\end{array}$ & Poirier et al., 2001 \\
\hline & Humans & 25-100 mg/day; orally; chronic & $\beta 1 \mathrm{AR}$ & $\begin{array}{l}\text { Insulin } \\
\text { resistance }\end{array}$ & Bharati and Singh 2016 \\
\hline & Humans & 50-100 mg/day; orally; chronic & $\beta 1 \mathrm{AR}$ & $\begin{array}{l}\text { Insulin } \\
\text { resistance }\end{array}$ & Sirenko et al., 2017 \\
\hline
\end{tabular}


This finding led to the discovery of a new class of drugs termed $\beta$-arrestin biased agonists (Ibrahim and Kurose, 2012; Ibrahim et al., 2013; Jean-Charles et al., 2017). The first member of this class was carvedilol, which was previously classified as $\beta$-blocker (Jean-Charles et al., 2017).

Recently, it has been found that $\beta$ arrestin signaling in some conditions may be G-protein dependent, in particular $\mathrm{G}_{\mathrm{i}}$-protein. Walters et al., 2009 showed that nicotinic acid-mediated activation of ERK is dependent on both $\mathrm{G}_{\mathrm{i}}$-protein and $\beta$-arrestin1 (Walters et al., 2009). In the same context, Wang et al., 2018 showed that mechano-activation of the angiotensin II type 1 receptor induced $\beta$ arrestin biased signaling through $\mathrm{G} \alpha_{\mathrm{i}}$-coupling (Wang et al., 2018). Moreover, Wang et al., 2017 showed that $G \alpha_{i}$ is required for carvedilol-induced $\beta 1 \mathrm{AR} \quad \beta$-arrestin biased signaling (Wang et al., 2017). $\beta 2$-Agonists acutely mediate hyperglycemia and insulin resistance by the activation of $\beta 2 \mathrm{AR} / \mathrm{G} \alpha_{\mathrm{s}} / \mathrm{AC} / \mathrm{cAMP} / \mathrm{PKA}$ pathway in the liver leading to hepatic glycogenolysis and gluconeogenesis and lipid hydrolysis with subsequent elevation of circulating FFAs in adipose tissue (Fig.2). However, persistent activation of $\beta 2 \mathrm{AR}$ shifts the coupling towards $\mathrm{G} \alpha_{\mathrm{i}}$-protein instead of $\mathrm{G} \alpha_{\mathrm{s}}$-subtype. Therefore, during chronic systemic administration of $\beta 2$ agonists the predominant pathway is the $\mathrm{G \alpha}_{\mathrm{i}^{-}}$ rather than $\mathrm{G} \alpha_{\mathrm{s}}$-protein dependent signaling pathway. Probably, this shift toward $\mathrm{G}_{\mathrm{i}^{-}}$ protein pathway may be associated with the activation of $\beta$-arrestin signaling, which improves glucose homeostasis and insulin sensitivity as mentioned earlier (Fig. 2). Supporting this assumption, a recent study showed that the clenbuterol-induced skeletal
ISSN (on-line) 2356_9786

muscle hypertrophy is both $\mathrm{G} \alpha_{\mathrm{i}} / \beta$-arrestin1 dependent (Kim et al., 2018). Although another recent study showed that clenbuterolinduced systemic glucose uptake is independent of the $\beta$-arrestin $1 / 2$ activity in the skeletal muscle (Meister et al., 2019), the role of $\mathrm{G} \alpha_{\mathrm{i}} / \beta$-arrestin pathway in liver and adipose tissue was not previously examined. Taking in consideration that the role of liver and adipose tissue is more prominent than that of skeletal muscle in mediating $\beta 2$-agonists systemic effects as we previously mentioned, it will be interesting to investigate the role of $\mathrm{G}_{\mathrm{i}} / \beta$ arrestin pathway in these tissues.

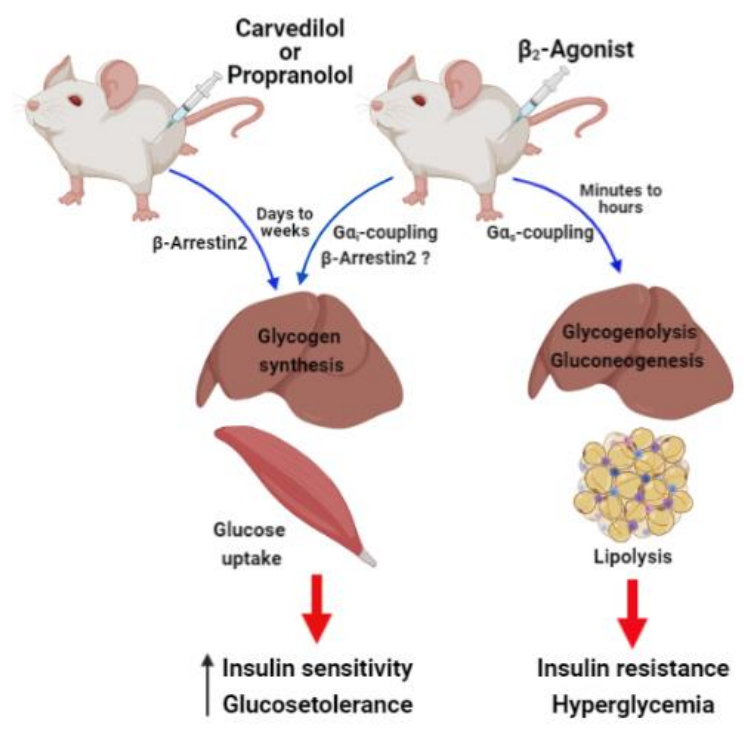

Figure 2: Acute and chronic effects of $\beta$-adrenergic receptor agonists and antagonists on glucose homeostasis:

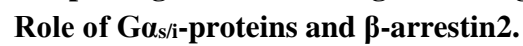

On the other hand, $\beta$-blockers such as propranolol have been found to acutely prolong hypoglycemia after insulin administration by blocking $\beta 2 \mathrm{ARs}$ leading to inhibition of hepatic glucose output and release of FFAs into the circulation. In the same context, propranolol has been found to activate $\beta$-arrestin signaling, which can mediate insulin sensitizing effects. Because, $\beta$-arrestin signaling is long lasting compared to G-protein 
signaling, the chronic effects of propranolol are more likely to be mediated by the former one. Interestingly, our work revealed a link between the chronic insulin sensitizing effects of propranolol and hepatic $\beta$-arrestin 2 signaling (data under publication) (Fig. 2). Similarly, carvedilol acute and chronic metabolic effects can be interpreted in the same way. Also, our work and another research group showed potential role for $\beta$-arrestin2 signaling in mediating the metabolic effects of carvedilol.

\section{Conclusion and future perspectives}

$\beta$-Adrenergic receptors can both induce and ameliorate insulin resistance depending on the $\beta$-adrenergic receptor subtype, the duration of stimulation and the type of affected tissue. Systemic use of $\beta 2$-agonists acutely mediates insulin resistance while improves it on longterm use. These opposing effects may be attributed to the shift from $\mathrm{G}_{\mathrm{s}}$-coupling in short-term use to $\mathrm{G} \alpha_{\mathrm{i}}$-coupling in long-term. Furthermore, $\mathrm{G} \alpha_{\mathrm{i}}$-coupling may mediate the insulin sensitizing effects by the activation of $\beta$-arrestin signaling especially in liver and adipose tissue. However, further future studies are required to confirm this assumption. On the other hand, the ability of certain types of $\beta$ blockers such as carvedilol and propranolol to chronically reduce systemic insulin resistance may be mediated by the activation of $\beta$-arrestin signaling .

\section{Reference}

Abreu RM, Santos DJ, \& Moreno AJ. (2000). Effects of carvedilol and its analog BM-910228 on mitochondrial function and oxidative stress. Journal of Pharmacology and Experimental Therapeutics, 295(3), 1022-1030.
Aggerbeck M, Ferry N, Zafrani E-S, Billon M, Barouki R, \& Hanoune J. (1983). Adrenergic regulation of glycogenolysis in rat liver after cholestasis. Modulation of the balance between alpha 1 and beta 2 receptors. The Journal of clinical investigation, 71(3), 476-486.

Akbas H, Ozden M, Kanko M, Maral H, Bulbul S, Yavuz S, et al. (2005). Protective antioxidant effects of carvedilol in a rat model of ischaemia-reperfusion injury. Journal of international medical research, 33(5), 528-536.

Akçay MN, Akçay G, \& öztürk G. (2005). The effects of metformin and oral propranolol on insulin resistance in thermally injured patients. The Pain Clinic, 17(2), 189-192.

Al-Ozairi E, Alsaeed D, Alroudhan D, Voase N, Hasan A, Gill JM, et al. (2021). Skeletal Muscle and Metabolic Health: How Do We Increase Muscle Mass and Function in People with Type 2 Diabetes? The Journal of Clinical Endocrinology \& Metabolism, 106(2), 309-317.

Alexander SP, Christopoulos A, Davenport AP, Kelly E, Mathie A, Peters JA, et al. (2019). The Concise Guide to PHARMACOLOGY 2019/20: G proteincoupled receptors. British journal of pharmacology, 176, S21-S141.

Allison S, Chamberlain M, Miller J, Ferguson R, Gillett A, Bemand B, et al. (1969). Effects of propranolol on blood sugar, insulin and free fatty acids. Diabetologia, 5(5), 339-342.

Arner P. (1992). Adrenergic receptor function in fat cells1-3. The American journal of clinical nutrition, 55(1), 228S-236S. 
ARNER P, ENGFELDT P, HELLSTRÖM L, LÖNNQVIST F, WAHRENBERG H, SONNENFELD T, et al. (1990). $\beta$ Adrenoreceptor subtype expression in human liver. The Journal of Clinical Endocrinology \& Metabolism, 71(5), 1119-1126.

Basat O, Ucak S, Seber S, Oztekin E, \& Altuntas Y. (2006). After myocardial infarction carvedilol improves insulin resistance compared to metoprolol. Clinical research in cardiology, 95(2), 99104.

Beg M, Abdullah N, Thowfeik FS, Altorki NK, \& McGraw TE. (2017). Distinct Akt phosphorylation states are required for insulin regulated Glut4 and Glut1mediated glucose uptake. Elife, 6, e26896.

Bharati SM, \& Singh N. (2016). Effect of losartan and atenolol on insulin sensitivity in nondiabetic hypertensive patients. Journal of pharmacology \& pharmacotherapeutics, 7(2), 80.

Bristow MR, Ginsburg R, Umans V, Fowler M, Minobe W, Rasmussen $\mathbf{R}$, et al. (1986). Beta 1-and beta 2-adrenergicreceptor subpopulations in nonfailing and failing human ventricular myocardium: coupling of both receptor subtypes to muscle contraction and selective beta 1receptor down-regulation in heart failure. Circulation research, 59(3), 297-309.

Burniston JG, Clark WA, Tan LB, \& Goldspink DF. (2006). Dose-dependent separation of the hypertrophic and myotoxic effects of the $\beta 2$-adrenergic receptor agonist clenbuterol in rat striated muscles. Muscle \& Nerve: Official Journal of the American Association of
Electrodiagnostic Medicine, 33(5), 655663.

Burniston JG, Tan L-B, \& Goldspink DF. (2005). $\beta 2$-Adrenergic receptor stimulation in vivo induces apoptosis in the rat heart and soleus muscle. Journal of applied physiology, 98(4), 1379-1386.

Campbell AP, \& Smrcka AV. (2018). Targeting $G$ protein-coupled receptor signalling by blocking $\mathrm{G}$ proteins. Nature reviews Drug discovery, 17(11), 789-803.

Cannavo A, Liccardo D, \& Koch WJ. (2013). Targeting cardiac $\beta$-adrenergic signaling via GRK2 inhibition for heart failure therapy. Frontiers in physiology, 4, 264.

Cerasi E, Luft R, \& Efendić S. (1972). Effect of adrenergic blocking agents on insulin response to glucose infusion in man. European Journal of Endocrinology, 69(2), 335-346.

Chen AE, Ginty DD, \& Fan C-M. (2005). Protein kinase A signalling via CREB controls myogenesis induced by Wnt proteins. Nature, 433(7023), 317-322.

Chiasson J-L, Shikama H, Chu DT, \& Exton JH. (1981). Inhibitory effect of epinephrine on insulin-stimulated glucose uptake by rat skeletal muscle. The Journal of clinical investigation, 68(3), 706-713.

Collins S. (2012). $\beta$-Adrenoceptor signaling networks in adipocytes for recruiting stored fat and energy expenditure. Frontiers in endocrinology, 2, 102.

Collins S, Cao W, \& Robidoux J. (2004). Learning new tricks from old dogs: $\beta$ adrenergic receptors teach new lessons on firing up adipose tissue metabolism. Molecular endocrinology, 18(9), 21232131. 
Collins S, \& Surwit RS. (2001). The betaadrenergic receptors and the control of adipose tissue metabolism and thermogenesis. Recent progress in hormone research, 56, 309-328.

Communal C, Singh K, Sawyer DB, \& Colucci WS. (1999). Opposing effects of $\beta 1$-and $\beta 2$-adrenergic receptors on cardiac myocyte apoptosis: role of a pertussis toxin-sensitive $\mathrm{G}$ protein. Circulation, 100(22), 2210-2212.

da Silva Franco N, Lubaczeuski C, Guizoni DM, Victorio JA, Santos-Silva JC, Brum PC, et al. (2017). Propranolol treatment lowers blood pressure, reduces vascular inflammatory markers and improves endothelial function in obese mice. Pharmacological research, 122, 35-45.

Daaka Y, Luttrell LM, \& Lefkowitz RJ. (1997). Switching of the coupling of the $\beta$ 2-adrenergic receptor to different $G$ proteins by protein kinase A. Nature, 390(6655), 88-91.

DAX EM, PARTILLA JS, PINEYRO MA, \& GREGERMAN RI. (1987). $\beta$ Adrenergic receptors, glucagon receptors, and their relationship to adenylate cyclase in rat liver during aging. Endocrinology, 120(4), 1534-1541.

De Oliveira PG, Ramos ML, Amaro AJ, Dias RA, \& Vieira SI. (2019). Gi/oprotein coupled receptors in the aging brain. Frontiers in aging neuroscience, 11, 89.

Deacon S. (1977). Effect of atenolol and other beta blockers on insulin-induced hypoglycaemia. Proceedings of the Royal Society of Medicine, 70(5_suppl), 50-52.

DeFronzo R. (1997). Insulin resistance: a multifaceted syndrome responsible for
NIDDM, obesity, hypertension, dyslipidaemia and atherosclerosis. The Netherlands journal of medicine, 50(5), 191-197.

DeFronzo RA, \& Ferrannini E. (1991). Insulin resistance: a multifaceted syndrome responsible for NIDDM, obesity, hypertension, dyslipidemia, and atherosclerotic cardiovascular disease. Diabetes care, 14(3), 173-194.

Dixon RA, Kobilka BK, Strader DJ, Benovic JL, Dohlman HG, Frielle T, et al. (1986). Cloning of the gene and cDNA for mammalian $\beta$-adrenergic receptor and homology with rhodopsin. Nature, 321(6065), 75-79.

Dwivedi H, Baidya M, \& Shukla AK. (2018). GPCR Signaling: The Interplay of Gai and $\beta$-arrestin. Current Biology, 28(7), R324R327.

El-Fayoumi SH, Mahmoud AAA, Fahmy A, Ibrahim IAAE-H (2020). Effect of omega-3 fatty acids on glucose homeostasis: role of free fatty acid receptor 1. Naunyn-Schmiedeberg's Archives of Pharmacology, 393(10), 1797-1808.

Emorine LJ, Marullo S, Briend-Sutren MM, Patey G, Tate K, Delavier-Klutchko C, et al. (1989). Molecular characterization of the human beta 3-adrenergic receptor. Science, 245(4922), 1118-1121.

Erraji-Benchekroun L, Couton D, Postic C, Borde I, Gaston J, Guillet J-G, et al. (2005). Overexpression of $\beta 2$-adrenergic receptors in mouse liver alters the expression of gluconeogenic and glycolytic enzymes. American Journal of PhysiologyEndocrinology and Metabolism, 288(4), E715-E722. 
Evans BA, Hutchinson DS, \& Summers RJ. (2013). $\quad \beta \quad$ 2-adrenoceptor-mediated regulation of glucose uptake in skeletal muscle-ligand-directed signalling or a reflection of system complexity? : Springer.

Feng X, Wang W, Liu J, \& Liu Y. (2011). $\beta$ Arrestins: multifunctional signaling adaptors in type 2 diabetes. Molecular biology reports, 38(4), 2517-2528.

Frielle T, Collins S, Daniel KW, Caron MG, Lefkowitz RJ, \& Kobilka BK. (1987). Cloning of the cDNA for the human beta 1adrenergic receptor. Proceedings of the National Academy of Sciences, 84(22), 7920-7924.

Fukushima M, Usami M, Ikeda M, Nakai Y, Taniguchi A, Matsuura T, et al. (2004). Insulin secretion and insulin sensitivity at different stages of glucose tolerance: a cross-sectional study of Japanese type 2 diabetes. Metabolism, 53(7), 831-835.

Ghosh PM, Shu Z-J, Zhu B, Lu Z, Ikeno Y, Barnes JL, et al. (2012). Role of $\beta$ adrenergic receptors in regulation of hepatic fat accumulation during aging. The Journal of endocrinology, 213(3), 251.

Glukhova A, Draper-Joyce CJ, Sunahara RK, Christopoulos A, Wootten D, \& Sexton PM. (2018). Rules of engagement: GPCRs and G proteins. ACS pharmacology \& translational science, 1(2), 73-83.

Gosmanov AR, Wong JA, \& Thomason DB. (2002). Duality of $G$ protein-coupled mechanisms for $\beta$-adrenergic activation of NKCC activity in skeletal muscle. American Journal of Physiology-Cell Physiology, 283(4), C1025-C1032.

Gray D, Lickley H, \& Vranic M. (1980). Physiologic effects of epinephrine on glucose turnover and plasma free fatty acid concentrations mediated independently of glucagon. Diabetes, 29(8), 600-609.

Greenberg AS, Shen W-J, Muliro K, Patel S, Souza SC, Roth RA, et al. (2001). Stimulation of lipolysis and hormonesensitive lipase via the extracellular signalregulated kinase pathway. Journal of Biological Chemistry, 276(48), 4545645461.

Groop L, Tötterman K, Harno K, \& Gordin A. (1983). Influence of Beta-Blocking Drugs on Glucose Metabolism in Hypertensive, Non-Diabetic Patients. Acta Medica Scandinavica, 213(1), 9-14.

Güven B, Kara Z, \& Onay-Beşikci A. (2020). Metabolic effects of carvedilol through $\beta$ arrestin proteins: investigations in a streptozotocin-induced diabetes rat model and in C2C12 myoblasts. British Journal of Pharmacology, 177(24), 5580-5594.

Haeusler RA, McGraw TE, \& Accili D. (2018). Biochemical and cellular properties of insulin receptor signalling. Nature reviews Molecular cell biology, 19(1), 31.

Hall RA. (2004). $\beta$-Adrenergic receptors and their interacting proteins. Paper presented at the Seminars in cell \& developmental biology.

Halls ML, \& Cooper DM. (2017). Adenylyl cyclase signalling complexespharmacological challenges and opportunities. Pharmacology \& therapeutics, 172, 171-180.

Heather L, Catchpole A, Stuckey D, Cole M, Carr C, \& Clarke K. (2009). Isoproterenol induces in vivo functional and metabolic abnormalities; similar to those found in the infarcted rat heart. Acta physiologica Polonica, 12(3), 31. 
Hoff R, \& Koh C-K. (2018). Isoproterenol induced insulin resistance leading to diabetic ketoacidosis in type 1 diabetes mellitus. Case reports in endocrinology, 2018.

Hunt DG, Ding Z, \& Ivy JL. (2002). Clenbuterol prevents epinephrine from antagonizing insulin-stimulated muscle glucose uptake. Journal of Applied Physiology, 92(3), 1285-1292.

Hunt DG, \& Ivy JL. (2002). Epinephrine inhibits insulin-stimulated muscle glucose transport. Journal of applied physiology, 93(5), 1638-1643.

Hurr C, Simonyan H, Morgan DA, Rahmouni K, Young CN. Liver sympathetic denervation reverses obesityinduced hepatic steatosis. The Journal of physiology. 2019 Sep 1;597(17):4565-80.

Ibrahim, I. A. H., \& Kurose, H. (2012). $\beta$ arrestin-mediated signaling improves the efficacy of therapeutics. Journal of pharmacological sciences, 118(4), 408412.

Ibrahim IAAE.-H, Nakaya M, Kurose H. (2013). Ezrin, radixin, and moesin phosphorylation in NIH3T3 cells revealed angiotensin II type 1 receptor cell-typedependent biased signaling. Journal of Pharmacological Sciences, 122(1), 1-9.

Ibrahim WS, Ibrahim IA-H, Mahmoud MF, \& Mahmoud AA. (2020). Carvedilol Diminishes Cardiac Remodeling Induced by High-Fructose/High-Fat Diet in Mice via Enhancing Cardiac $\beta$-Arrestin2 Signaling. Journal of cardiovascular pharmacology and therapeutics, 25(4), 354-363.

Jacob S. (1999). Beta-blocking agents in patients with insulin resistance: effects of vasodilating beta-blockers. Blood pressure, 8(5-6), 261-268.

Jean-Charles P-Y, Kaur S, \& Shenoy SK. (2017). GPCR signaling via $\beta$-arrestindependent mechanisms. Journal of cardiovascular pharmacology, 70(3), 142.

Kalinovich A, Dehvari N, Åslund A, van Beek S, Halleskog C, Olsen J, et al. (2020). Treatment with a $\beta$-2-adrenoceptor agonist stimulates glucose uptake in skeletal muscle and improves glucose homeostasis, insulin resistance and hepatic steatosis in mice with diet-induced obesity. Diabetologia, 63, 1603-1615.

Katz MS, McNair CL, Hymer TK, \& Boland SR. (1987). Emergence of beta adrenergic-responsive hepatic glycogenolysis in male rats during postmaturational aging. Biochemical and biophysical research communications, 147(2), 724-730.

Khoury N, \& McGill JB. (2011). Reduction in insulin sensitivity following administration of the clinically used lowdose pressor, norepinephrine. Diabetes/metabolism research and reviews, 27(6), 604-608.

Kim YS, Sainz RD, Molenaar P, \& Summers RJ. (1991). Characterization of $\beta 1$-and $\beta 2$-adrenoceptors in rat skeletal muscles. Biochemical pharmacology, 42(9), 1783-1789.

Kim J, Grotegut CA, Wisler JW, Li T, Mao L, Chen M, Chen W, Rosenberg PB, Rockman HA, Lefkowitz RJ. $\beta$-arrestin 1 regulates $\beta 2$-adrenergic receptor-mediated skeletal muscle hypertrophy and contractility. Skeletal muscle. 2018 Dec;8(1):1-3. 
Kuperstein R, \& Sasson Z. (2000). Effects of antihypertensive therapy on glucose and insulin metabolism and on left ventricular mass: a randomized, double-blind, controlled study of 21 obese hypertensives. Circulation, 102(15), 1802-1806.

Lefkowitz RJ. (1998). G protein-coupled receptors III. New roles for receptor kinases and $\beta$-arrestins in receptor signaling and desensitization. Journal of Biological Chemistry, 273(30), 1867718680.

Liu YL, Cawthorne MA, \& Stock MJ. (1996). Biphasic effects of the $\beta$ adrenoceptor agonist, BRL 37344, on glucose utilization in rat isolated skeletal muscle. British journal of pharmacology, 117(6), 1355-1361.

Luan B, Zhao J, Wu H, Duan B, Shu G, Wang $X$, et al. (2009). Deficiency of a $\beta$ arrestin-2 signal complex contributes to insulin resistance. Nature, 457(7233), 1146-1149.

Luttrell, L. M. (2005). Composition and function of $\mathrm{G}$ protein-coupled receptor signalsomes controlling mitogen-activated protein kinase activity. Journal of molecular neuroscience, 26(2), 253-264.

Lyngsøe J, Lauridsen UB, \& Christensen N. (1983). Effects of Atenolol and Propranolol on Glucose Metabolism and Hormonal Responses during Insulininduced Hypoglycaemia in Normal Man. Drugs, 25(2), 237-240.

Madamanchi A. (2007). $\beta$-Adrenergic receptor signaling in cardiac function and heart failure. McGill Journal of Medicine: MJM, 10(2), 99.

Marangou AG, Alford FP, Ward G, Liskaser F, Aitken PM, Weber KM, ... \&
Best JD. (1988). Hormonal effects of norepinephrine on acute glucose disposal in humans: a minimal model analysis. Metabolism, 37(9), 885-891.

Martin 3rd W, Murphree S, \& Saffitz J. (1989). Beta-adrenergic receptor distribution among muscle fiber types and resistance arterioles of white, red, and intermediate skeletal muscle. Circulation Research, 64(6), 1096-1105.

McGuinness OP, Shau V, Benson EM, Lewis M, Snowden RT, Greene JE, et al. (1997). Role of epinephrine and norepinephrine in the metabolic response to stress hormone infusion in the conscious dog. American Journal of PhysiologyEndocrinology And Metabolism, 273(4), E674-E681.

Meister J, Bone DB, Godlewski G, Liu Z, Lee RJ, Vishnivetskiy SA, Gurevich VV, Springer D, Kunos G, Wess J. Metabolic effects of skeletal muscle-specific deletion of beta-arrestin-1 and-2 in mice. PLoS genetics. 2019 Oct 17;15(10):e1008424.

Melvin A, O'Rahilly S, \& Savage D. (2018). Genetic syndromes of severe insulin resistance. Current opinion in genetics \& development, 50, 60-67.

Mohammed SG, Ibrahim IAAEH, Mahmoud MF, Mahmoud AAA. (2019). Carvedilol protects against hepatic ischemia/reperfusion injury in highfructose/high-fat diet-fed mice: Role of $\mathrm{G}$ protein-coupled receptor kinase 2 and 5 . Toxicology and Applied Pharmacology, 382, 114750

Moniotte S, Kobzik L, Feron O, Trochu JN, Gauthier C, \& Balligand J-L. (2001). Upregulation of $\beta 3$-adrenoceptors and altered contractile response to inotropic amines in human failing myocardium. Circulation, 103(12), 1649-1655. 
Mulder AH, Tack CJ, Olthaar AJ, Smits P, Sweep FC, \& Bosch RR. (2005). Adrenergic receptor stimulation attenuates insulin-stimulated glucose uptake in 3T3L1 adipocytes by inhibiting GLUT4 translocation. American Journal of Physiology-Endocrinology and Metabolism, 289(4), E627-E633.

Murga $\mathbf{C}$, Laguinge L, Wetzker R, Cuadrado A, \& Gutkind JS. (1998). Activation of Akt/Protein Kinase B by G protein-coupled receptors: a role for $\alpha$ and $\beta \gamma$ subunits of heterotrimeric g proteins acting through phosphatidylinositol-3-OH kinasey. Journal of Biological Chemistry, 273(30), 19080-19085.

Nachar RA, Booth EA, Friedlich P, Borzage M, Soleymani S, Wider MD, et al. (2011). Dose-dependent hemodynamic and metabolic effects of vasoactive medications in normotensive, anesthetized neonatal piglets. Pediatric research, 70(5), 473-479.

Ngala RA, O'Dowd JF, Stocker CJ, Cawthorne MA, Arch JR. (2013). $\beta 2$ adrenoceptor agonists can both stimulate and inhibit glucose uptake in mouse soleus muscle through ligand-directed signalling. Naunyn-Schmiedeberg's archives of pharmacology, 386(9), 761773.

Nandipati KC, Subramanian S, \& Agrawal DK. (2017). Protein kinases: mechanisms and downstream targets in inflammationmediated obesity and insulin resistance. Molecular and cellular biochemistry, 426(1-2), 27-45.

Ozylldız AG, Eroglu S, Bal U, Atar I, Okyay K, \& Muderrisoglu H. (2017). Effects of carvedilol compared to nebivolol on insulin resistance and lipid profile in patients with essential hypertension. Journal of cardiovascular pharmacology and therapeutics, 22(1), 65-70.

Palomer X, Pizarro-Delgado J, Barroso E, \& Vázquez-Carrera M. (2018). Palmitic and oleic acid: the yin and yang of fatty acids in type 2 diabetes mellitus. Trends in Endocrinology \& Metabolism, 29(3), 178190.

Pan SJ, Hancock J, Ding Z, Fogt D, Lee M, \& Ivy JL. (2001). Effects of clenbuterol on insulin resistance in conscious obese Zucker rats. American Journal of Physiology-Endocrinology And Metabolism, 280(4), E554-E561.

Patil P, \& Watve M. (2010). Hyperinsulinemia and insulin resistance: What comes first? Nature Precedings, 1-1.

Penesova A, Radikova Z, Cizmarova E, Kvetňanský R, Blazicek $P$, Vlcek $M$, et al. (2008). The role of norepinephrine and insulin resistance in an early stage of hypertension. Annals of the New York Academy of Sciences, 1148(1), 490-494.

Petersen MC, \& Shulman GI. (2018). Mechanisms of insulin action and insulin resistance. Physiological reviews, 98(4), 2133-2223.

Philipson L. (2002). $\beta$-Agonists and metabolism. Journal of allergy and clinical immunology, 110(6), S313-S317.

Poirier L, Cléroux J, Nadeau $A, \&$ Lacourcière Y. (2001). Effects of nebivolol and atenolol on insulin sensitivity and haemodynamics in hypertensive patients. Journal of hypertension, 19(8), 1429-1435.

Pollare T, Lithell H, Selinus I, \& Berne C. (1989). Sensitivity to insulin during treatment with atenolol and metoprolol: a randomised, double blind study of effects on carbohydrate and lipoprotein metabolism in hypertensive patients. British Medical Journal, 298(6681), 11521157.

Reddy KJ, Singh M, Bangit JR, \& Batsell RR. (2010). The role of insulin resistance in the pathogenesis of atherosclerotic cardiovascular disease: an updated review. Journal of Cardiovascular Medicine, 11(9), 633-647. 
Reneland R, Alvarez E, Andersson P, Haenni A, Byberg L, \& Lithell H. (2000). Induction of insulin resistance by betablockade but not ACE-inhibition: longterm treatment with atenolol or trandolapril. Journal of human hypertension, 14(3), 175-180.

Rezk AM, Ibrahim IA, Mahmoud MF, Mahmoud AA. Quercetin and lithium chloride potentiate the protective effects of carvedilol against renal ischemiareperfusion injury in high-fructose, highfat diet-fed Swiss albino mice independent of renal lipid signaling. ChemicoBiological Interactions. 2021 Jan 5;333:109307.

Rockman HA, Koch WJ, \& Lefkowitz RJ. (2002). Seven-transmembrane-spanning receptors and heart function. Nature, 415(6868), 206-212.

Rolo AP, Oliveira PJ, Moreno AJ, \& Palmeira CM. (2003). Chenodeoxycholate induction of mitochondrial permeability transition pore is associated with increased membrane fluidity and cytochrome c release: protective role of carvedilol. Mitochondrion, 2(4), 305-311.

Rousseau-Migneron S, Nadeau A, \& Tancrède G. (1980). Effects of isoproterenol on insulin and glucagon secretion in rats treated chronically with isoproterenol. Canadian journal of physiology and pharmacology, 58(3), 275280.

Routledge P, \& Shand D. (1979). Clinical pharmacokinetics of propranolol. Clinical Pharmacokinetics, 4(2), 73.

Ryall JG, Gregorevic P, Plant DR, Sillence MN, \& Lynch GS. (2002). $\beta 2$-Agonist fenoterol has greater effects on contractile function of rat skeletal muscles than clenbuterol. American Journal of Physiology-Regulatory, Integrative and Comparative Physiology, 283(6), R1386R1394.
Ryall JG, Plant DR, Gregorevic P, Sillence MN, \& Lynch GS. (2004). $\beta 2$-Agonist administration reverses muscle wasting and improves muscle function in aged rats. The Journal of physiology, 555(1), 175188.

Ryall JG, Sillence MN, \& Lynch GS. (2006). Systemic administration of $\beta 2$ adrenoceptor agonists, formoterol and salmeterol, elicit skeletal muscle hypertrophy in rats at micromolar doses. British journal of pharmacology, 147(6), 587-595.

Sato M, Dehvari N, Öberg AI, Dallner OS, Sandström AL, Olsen JM, et al. (2014). Improving type 2 diabetes through a distinct adrenergic signaling pathway involving mTORC2 that mediates glucose uptake in skeletal muscle. Diabetes, 63(12), 4115-4129.

Sherwin RS, \& Sacca L. (1984). Effect of epinephrine on glucose metabolism in humans: contribution of the liver. American Journal of PhysiologyEndocrinology And Metabolism, 247(2), E157-E165.

Shimobayashi M, Albert V, Woelnerhanssen B, Frei IC, Weissenberger D, Meyer-Gerspach AC, et al. (2018). Insulin resistance causes inflammation in adipose tissue. The Journal of clinical investigation, 128(4), 1538-1550.

Sirenko Y, Rekovets O, Torbas O, Savitskiy S, \& Pavlyuk E. (2017). Effect of BetaBlockers on Insulin Resistance in Patients with Hypertension and Metabolic Syndrome after 6 Months of Treatment. Journal of Endocrinology and Diabetes, 4, 1-11.

Soeder KJ, Snedden SK, Cao W, Della Rocca GJ, Daniel KW, Luttrell LM, et al. (1999). The $\beta 3$-adrenergic receptor activates mitogen-activated protein kinase in adipocytes through a Gi-dependent 
Zagazig J. Pharm. Sci. Dec, 2021

Vol. 30, Issue 2, pp. 1- 21

mechanism. Journal of Biological Chemistry, 274(17), 12017-12022.

Spiller HA, James KJ, Scholzen S, \& Borys DJ. (2013). A descriptive study of adverse events from clenbuterol misuse and abuse for weight loss and bodybuilding. Substance abuse, 34(3), 306-312.

Tilley DG, \& Rockman HA. (2006). Role of $\beta$-adrenergic receptor signaling and desensitization in heart failure: new concepts and prospects for treatment. Expert review of cardiovascular therapy, 4(3), 417-432.

Wadworth AN, Murdoch D, \& Brogden RN. (1991). Atenolol. Drugs, 42(3), 468-510.

Walters RW, Shukla AK, Kovacs JJ, Violin JD, DeWire SM, Lam CM, et al. (2009). $\beta$-Arrestin1 mediates nicotinic acidinduced flushing, but not its antilipolytic effect, in mice. The Journal of clinical investigation, 119(5), 1312-1321.

Wang Y, Nishina PM, Naggert JK. Degradation of IRS1 leads to impaired glucose uptake in adipose tissue of the type 2 diabetes mouse model TALLYHO/Jng. J Endocrinol. 2009 Oct;203(1):65.

Wang J, Hanada K, Gareri C, \& Rockman HA. (2018). Mechanoactivation of the angiotensin II type 1 receptor induces $\beta$ arrestin-biased signaling through Gai coupling. Journal of cellular biochemistry, 119(4), 3586-3597.

Wang J, Hanada K, Staus DP, Makara MA, Dahal GR, Chen Q, et al. (2017). G $\alpha$ i is required for carvedilol-induced $\beta 1$ adrenergic receptor $\beta$-arrestin biased signaling. Nature communications, 8(1), 114.

Wang Y, De Arcangelis V, Gao X, Ramani B, Jung Y-s, \& Xiang Y. (2008). Norepinephrine-and epinephrine-induced distinct $\beta 2$-adrenoceptor signaling is dictated by GRK2 phosphorylation in cardiomyocytes. Journal of Biological Chemistry, 283(4), 1799-1807.
ISSN 1110-5089

ISSN (on-line) 2356_9786

Ward KD, Sparrow D, Landsberg L, Young JB, Vokonas PS, \& Weiss ST. (1994). The relationship of epinephrine excretion to serum lipid levels: the Normative Aging Study. Metabolism, 43(4), 509-513.

Wilcox G. (2005). Insulin and insulin resistance. Clinical biochemist reviews, 26(2), 19.

Williams RS, Caron MG, \& Daniel K. (1984). Skeletal muscle beta-adrenergic receptors: variations due to fiber type and training. American Journal of PhysiologyEndocrinology And Metabolism, 246(2), E160-E167.

Wisler, J. W., DeWire, S. M., Whalen, E. J., Violin, J. D., Drake, M. T., Ahn, S., ... \& Lefkowitz, R. J. (2007). A unique mechanism of $\beta$-blocker action: carvedilol stimulates $\quad \beta$-arrestin signaling. Proceedings of the National Academy of Sciences, 104(42), 1665716662.

Wong DL, Tai T, Wong-Faull DC, Claycomb R, Meloni EG, Myers KM, et al. (2012). Epinephrine: A short-and longterm regulator of stress and development of illness. Cellular and molecular neurobiology, 32(5), 737-748.

Wu H, \& Ballantyne CM. (2017). Skeletal muscle inflammation and insulin resistance in obesity. The Journal of clinical investigation, 127(1), 43-54.

Wurtman JJ, Wurtman RJ, Growdon JH, Henry P, Lipscomb A, \& Zeisel SH. (1981). Carbohydrate craving in obese people: suppression by treatments affecting serotoninergic transmission. International Journal of Eating Disorders, 1(1), 2-15.

Xiang Y, Devic E, \& Kobilka B. (2002). The PDZ binding motif of the $\beta 1$ adrenergic receptor modulates receptor trafficking and signaling in cardiac myocytes. Journal of Biological Chemistry, 277(37), 3378333790.

Xiao R-P, Avdonin P, Zhou Y-Y, Cheng H, Akhter SA, Eschenhagen T, et al. (1999). 
Coupling of $\beta 2$-adrenoceptor to Gi proteins and its physiological relevance in murine cardiac myocytes. Circulation research, 84(1), 43-52.

Yaribeygi H, Farrokhi FR, Butler AE, \& Sahebkar A. (2019). Insulin resistance: Review of the underlying molecular mechanisms. Journal of cellular physiology, 234(6), 8152-8161.

Zamah AM, Delahunty M, Luttrell LM, \& Lefkowitz RJ. (2002). Protein kinase Amediated phosphorylation of the $\beta 2$ adrenergic receptor regulates its coupling to $\mathrm{Gs}$ and $\mathrm{Gi}$ : demonstration in a reconstituted system. Journal of Biological Chemistry, 277(34), 31249-31256.
Zhang T, Maier LS, Dalton ND, Miyamoto S, Ross Jr J, Bers DM, et al. (2003). The $\delta \mathrm{C}$ isoform of CaMKII is activated in cardiac hypertrophy and induces dilated cardiomyopathy and heart failure. Circulation research, 92(8), 912-919.

Zhu L, Rossi M, Cui Y, Lee RJ, Sakamoto W, Perry NA, et al. (2017). Hepatic $\beta$ arrestin 2 is essential for maintaining euglycemia. The Journal of clinical investigation, 127(8), 2941-2945.

Zuppa AF, \& Barrett JS. (2008). Pharmacokinetics and pharmacodynamics in the critically ill child. Pediatric clinics of North America, 55(3), 735-755. 


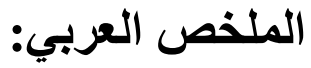 \\ دور مستقبلات بينا الأدرينالية في مقاومة الأنسولين: تحفيز ام منع ؟ وائل ابراهيم - اسلام ابراهيم - عمرو محمود - منى محمود}

مستقبلات بيتا الأدرينالية ، خاصة النوع الفرعي 2 ، هي منظم رئيسي لتوازن الجلوكوز . أظهرت الدر اسات

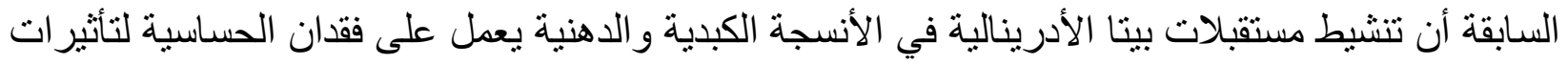

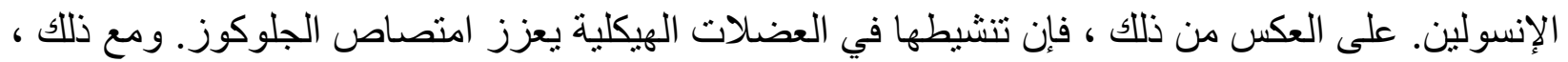

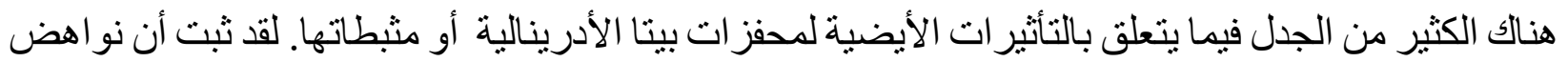
البيتا-2 تضعف إلى حد كبير توازن الجلوكوز في حين انها تحسنه من خلال الإستخدام طويل المدى. في نفس فئس

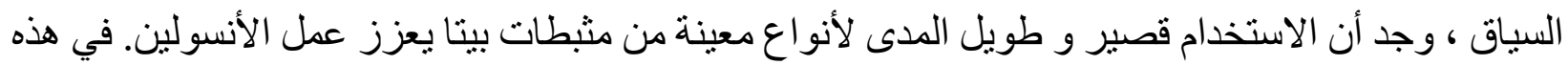

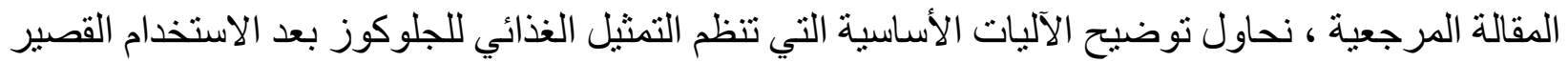

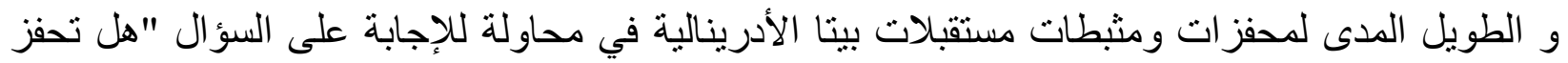

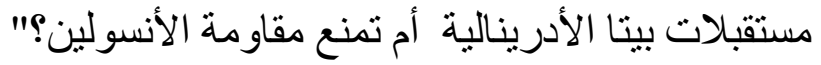

